\title{
PENINGKATAN AKTIVITAS DAN HASIL BELAJAR MATEMATIKA TEMA PENGALAMANKU DENGAN MODEL PEMBELAJARAN COURSE REVIEW HORAY
}

\section{Suprihartini $^{\bowtie}$}

SD 3 Tenggeles Mejobo Kudus

\section{Info Artikel Abstract \\ Sejarah Artikel: \\ Diterima 1 Okt 2019 \\ Direvisi 4 Nov 2019 \\ Disetujui 11 Nov \\ 2019 \\ Keywords: \\ Course Review Horay, \\ Experience, Activity. \\ Paper type: \\ Research paper \\ The purpose of this study is for the learning activities and learning outcomes of the theme of my experience with the review course horay learning model for first grade students of SD 3 Tenggeles semester II of the 2017/2018 Academic Year. Classroom action research was carried out on first grade students of SD 3 Tenggeles in the first semester of the 2017/208 Academic Year with 15 students consisting of 7 male students and 8 female students. The method used in this research is classroom action research consisting of 2 cycles, each cycle consisting of 4 stages: planning, acting, observing, and reflecting. In cycles 1 and 2 the actions taken with the course review horay learning model. The results of the study are based on the results of the study and discussion, it was concluded that the use of the course review horay learning model can increase the activities and learning outcomes of mathematics in my experience theme for grade 1 students of SD 3 Tenggeles Mejobo Subdistrict, Kudus Regency Semester II, 2017/2018 Academic Year. As an indication: (1) The mathematics learning activities of my experience theme continue to increase in each cycle. The initial conditions of learning activities 69, the first cycle increased to 74 and the second cycle reached 78 . From the initial conditions to the final conditions an increase of 9; (2) The mathematics learning outcomes of my experience theme continue to increase in each cycle. The initial conditions of learning outcomes 69, the first cycle increased to 72 and the second cycle reached 88. From the initial conditions to the final conditions an increase of 20.}

\begin{abstract}
Abstrak
Tujuan penelitian ini adalah untuk aktivitas dan hasil belajar matematika tema pengalamanku dengan model pembelajaran course review horay bagi siswa kelas I SD 3 Tenggeles semester II Tahun Pelajaran 2017/2018. Penelitian tindakan kelas dilakukan pada siswa kelas I SD 3 Tenggeles semester I Tahun Pelajaran 2017/2018dengan jumlah siswa 15 terdiri dari 7 siswa putra dan 8 siswa putri. Metode yang digunakan dalam penelitian ini adalah penelitian tindakan kelas yang terdiri dari 2 siklus, masing-masing siklus terdiri dari 4 tahapan yaitu perencanaan, pelaksanaan, pengamatan, dan refleksi. Pada siklus 1 dan 2 tindakan yang dilakukan dengan model pembelajaran course review horay. Hasil penelitian berdasarkan hasil penelitian dan pembahasan, disimpulkan bahwa penggunaan model pembelajaran course review horay dapat meningkatkan aktivitas dan hasil belajar matematika tema pengalamanku bagi siswa kelas I SD 3 Tenggeles Kecamatan Mejobo Kabupaten Kudus Semester II Tahun Pelajaran 2017/2018. Sebagai indikasinya: (1) Aktivitas belajar matematika tema pengalamanku terus meningkat pada tiap siklus. Kondisi awal aktivitas belajar 69, siklus I meningkat menjadi 74 dan siklus II mencapai 78. Dari kondisi awal ke kondisi akhir terjadi peningkatan sebesar 9; (2) Hasil belajar matematika tema pengalamanku terus meningkat pada tiap siklus. Kondisi awal hasil belajar 69, siklus I meningkat menjadi 72 dan siklus II mencapai 88. Dari kondisi awal ke kondisi akhir terjadi peningkatan sebesar 20.
\end{abstract}

(C) 2019 Universitas Muria Kudus

\footnotetext{
Alamat korespondensi:

Program Studi Pendidikan Matematika

Fakultas Keguruan dan Ilmu Pendidikan Universitas Muria Kudus

Kampus UMK Gondangmanis, Bae Kudus Gd. L. 1t I PO. BOX 53 Kudus

Tlp (0291) 438229 ex.147 Fax. (0291) 437198

E-mail: suprihartini.sd@gmail.com
}

p-ISSN 2615-4196

e-ISSN 2615-4072 


\section{PENDAHULUAN}

Keberhasilan pembelajaran dapat dilihat dari kualitas siswa. Apabila siswa mampu menguasai apa yang akan pelajari sesuai dengan tujuan pembelajaran yang diharapkan maka dapat dipastikan keberhasilan pembelajaran telah tercapai. Cara untuk mencapai hal tersebut tidak terlepas dari peran serta guru untuk menciptakan suasana belajar yang kondusif, sehingga dapat meningkatkan pemahaman siswa tentang materi yang akan dipelajari khususnya dalam mata pelajaran matematika.

Guru harus mampu menggunakan model pembelajaran yang sesuai dengan situasi dan kondisi yang ada di kelas. Jika guru tidak mampu menciptakan suasana belajar yang kondusif, akan mengakibatkan suasana belajar menjadi sangat pasif, sehingga semangat belajar siswa akan lemah dan berakibat pada aktivitas dan hasil belajar siswa yang rendah. Seperti pada siswa kelas $1 \mathrm{SD}$ 3 tenggelas kecamatan mejobo kabupaten kudus, dimana kondisi awal hasil belajar siswa cukup rendah. Rata-rata siswa hanya mencapai poin 69 saja, sedangkan kkm matematika adalah 75 .

Di sisi lain, pelajaran matematika perlu diberikan kepada semua siswa mulai dari sekolah dasar untuk membekali siswa dengan kemampuan berpikir logis, analitis, sistematis, kritis, dan kreatif, serta kemampuan bekerjasama. Kompetensi tersebut diperlukan agar siswa dapat memiliki kemampuan memperoleh, mengelola, dan memanfaatkan informasi untuk bertahan hidup pada keadaan yang selalu berubah, tidak pasti, dan kompetitif.

Salah satu upaya yang dapat dilakukan guru guna dapat meningkatkan mutu pendidikan melalui peningkatkan aktivitas dan hasil belajar siswa, yaitu dengan menggunakan berbagai model pembelajaran terbaru yang sedang marak diterapkan oleh kalangan guru-guru kreatif. Salah satu model yang cukup efektif untuk menunjang keberhasilan belajar siswa adalah model pembelajaran course review horay.

Model pembelajaran ini merupakan metode pembelajaran yang dapat menciptakan suasana kelas menjadi meriah dan menyenangkan karena setiap siswa yang dapat menjawab pertanyaan dengan benar, diwajibkan berteriak "hore!!" atau yel-yel lainnya yang disukai. Course review horay merupakan model pembelajaran yang menyenangkan karena setiap siswa yang dapat menjawab dengan benar, wajib berteriak "horee!!". Selain dapat meningkatkan pemahaman siswa, pembelajaran ini pun dapat meningkatkan motivasi belajar. Model pembelajaran ini juga membuat siswa menjadi aktif dalam pembelajaran (Huda, 2013:230).

Melalui model pembelajaran "bermain" ini siswa bisa belajar dengan menyenangkan tanpa ada rasa tertekan dengan materi yang sedang dipelajari. Model pembelajaran course review horay dapat membuat siswa dengan mudah menyerap konsep-konnsep yang dipelajari, sebab siswa terjun langsung dalam memecahkan masalah dalam belajar. Dan harapannya, aktivitas dan hasil belajar matematika dapat ditingkatkan.

Tujuan penelitian ini adalah: (1) peningkatan aktivitas belajar matematika tema pengalamanku bagi siswa, (2) peningkatan hasil belajar matematika tema pengalamanku bagi siswa dengan model pembelajaran course review horay.

Selain itu, penelitian tindakan kelas ini diharapkan memberikan manfaat bagi: (1) bagi siswa: (a) dapat meningkatnya aktivitas belajar matematika tema pengalamanku, (b) dapat meningkatnya hasil belajar matematika tema pengalamanku; (2) bagi peneliti: (a) melalui model pembelajaran course review horay dapat meningkatkan aktivitas belajar matematika tema pengalamanku bagi siswa, (b) melalui model pembelajaran course review horay dapat meningkatkan hasil belajar matematika tema pengalamanku bagi siswa; (3) bagi sekolah: dapat membantu meningkatkan mutu pendidikan dan memperbaiki citra sekolah di masyarakat, tentang mutu pendidikan sekolah.

Aktivitas merupakan segala kegiatan yang dilaksanakan baik secara jasmani atau rohani. Aktivitas belajar adalah keterlibatan siswa dalam bentuk sikap, pikiran, perhatian dan aktivitas dalam kegiatan pembelajaran guna menunjang keberhasilan proses belajar mengajar dan memperoleh manfaat (Kunandar, 2013:277).

Indikator aktivitas belajar dalam penelitian ini adalah: (1) siswa mengikuti arahan guru dengan baik, (2) siswa semangat mengucapkan horay, (3) siswa dengan baik melaksanakan diskusi, (4) siswa dengan baik mengikuti guru mengambil kesimpulan.

Dan belajar merupakan aktivitas mental atau psikis yang bertujuan untuk merubah tingkah laku seseorang. Belajar merupakan suatu proses, suatu kegiatan dan bukan suatu hasil atau tujuan (Hamalik, 2011:27). Belajar menurut Gagne adalah perubahan disposisi atau kemampuan yang dicapai seseorang melalui aktivitas (Suprijono, 2012:2). Belajar juga merupakan proses melihat, mengamati, dan memahami sesuatu (Rusman, 2011:1).

Hakikatnya belajar merupakan suatu usaha yang dilakukan oleh seseorang dengan jalan 
berinteraksi dengan individu lain dan dengan lingkungannya untuk memperoleh suatu pengalaman sehingga dapat mengalami suatu perubahan perilaku (Thobroni, 2015:14).

Pengertian mudan dari hasil belajar adalah prestasi aktual yang ditampilkan oleh siswa sedangkan usaha adalah perbuatan yang terarah pada penyelesaian tugas-tugas belajar. Ini berarti bahwa besarnya usaha adalah indikator dari adanya motivasi sedangkan hasil belajar dipengaruhi oleh besarnya usaha yang dilakukan oleh siswa (Sardiman, 2012: 25).

Menurut Reys matematika adalah telaah tentang pola dan hubungan, suatu jalan atau pola pikir, suatu seni, suatu bahasa dan suatu alat (Karso, 2014:1.40).

Menurut Johnson matematika adalah pola pikir, pola mengorganisasikan, pembuktian yang logis, matemtika itu adalah bahasa yang menggunakan istilah yang didefinisikan dangan cermat, jelas dan akurat reprsentasinya dengan simbol dan padat, lebih berupa bahasa simbol mengenai ide daripada mengenai bunyi Matematika adalah pengetahuan struktur yang terorganisasi, sifat-sifat dalam teori-teori dibuat secara deduktif berdasarkan kepada unsur yang tidak didefinisaikan, aksioma sifat atau teori yang telah di buktiakan kebenerannya adalah ilmu tentang keteraturan pola atau ide, dan matematika itu adalah suatu seni, keindahanya terdapat pada keterurutan dan keharmonisannya (Suwangsih, 2010: 4).

Ruang lingkup mata pelajaran matematika pada satuan pendidikan SD/MI meliputi aspek-aspek (Permendiknas Nomor 22 tahun 2006 tentang: Standar Isi untuk satuan pendidikan dasar dan menengah) sebagai berikut: (1) Bilangan, (2) Geometri dan pengukuran, (3) Pengolahan data.

Model pembelajaran course review horay merupakan suatu model pembelajaran dengan pengujian pemahaman menggunakan kotak-kotak yang diisi dengan nomor untuk menuliskan jawabannya. Yang paling dulu mendapatkan tanda benar vertikal atau horizontal, atau diagonal langsung berteriak "hore..".

Course review horay merupakan model pembelajaran yang menyenangkan karena setiap siswa yang dapat menjawab dengan benar, wajib berteriak "horee!!". Selain dapat meningkatkan pemahaman siswa, pembelajaran ini pun dapat meningkatkan motivasi belajar. Model pembelajaran ini juga membuat siswa menjadi aktif dalam pembelajaran (Huda, 2013:230).

Langkah-langkah model pembelajaran course review horay sendiri adalah sebagai berikut
(Huda, 2013:230): (1) Guru menyampaikan kompetensi yang ingin dicapai, (2) Guru menyajikan materi pelajaran sesuai dengan topik, (3) Guru membagi siswa dalam kelompokkelompok, (4) Siswa diminta membuat kartu atau kotak sesuai dengan kebutuhan. Kartu atau kotak tersebut kemudian diisi dengan nomor yang ditentukan guru, (5) Guru membaca soal secara acak dan siswa menuliskan jawabannya di dalam kartu atau kotak yang nomornya disebutkan guru, (6) Setelah pembacaan soal dan jawaban siswa ditulis di dalam kartu atau kotak, guru dan siswa mendiskusikan soal yang telah diberikan tadi, (7) Bagi pertanyaan yang dijawab dengan benar, siswa memberi tanda check list $(\sqrt{ })$ dan langsung berteriak "horee!!" atau menyanyikan yel-yelnya, (8) Nilai siswa dihitung dari jawaban yang benar dan yang banyak berteriak "horee!!", (9) Guru memberikan reward kepada kelompok yang mmeperoleh nilai tertinggi atau yang paling sering memperoleh "horee!!".

Sementara kelebihan model pembelajaran ini adalah (Huda, 2013:231): (1) Strukturnya yang menarik dan dapat mendorong siswa untuk dapat terjun ke dalamnya, (2) Model yang tidak monoton karena diselingi dengan hiburan, sehingga suasana tidak menegangkan, (3) Semangat belajar yang meningkat karena suasana pembelajaran berlangsung menyenangkan, (4) Skill kerja sama antar siswa semakin terlatih.

Penelitian yang dilakukan peneliti ini mendapatkan inspirasi dari: (1) Saputri, Mawar Kuning Nugraheni. (2016). Mawar Kuning Nugraheni Saputri melakukan penelitian pada tahun 2016 dengan judul "Penerapan model cooperative learning tipe course review horay untuk meningkatkan aktivitas dan hasil belajar matematika siswa kelas IV SD Negeri 1 Metro Timur"; (2) Rusita, Evi. (2017). Evi Rusita pada tahun 2017 melakukan penelitian dengan judul'Penerapan Metode Course Review Horay (CRH) Pada Pembelajaran Matematika Siswa Kelas IV di SD Negeri 03 Nangsri Kebakkramat Karanganyar Tahun Ajaran 2017/2018”. Pada kedua penelitian tersebut persamaan dengan penelitian ini yaitu penggunaan metode Course Review Horay pada pembelajaran matematika untuk meningkatkan aktivitas dan hasil belajar matematika. Sedangkan perbedaannya subyek penelitian dan materi penelitian.

Gambaran skema peneliti seperti tersebut di bawah ini. 


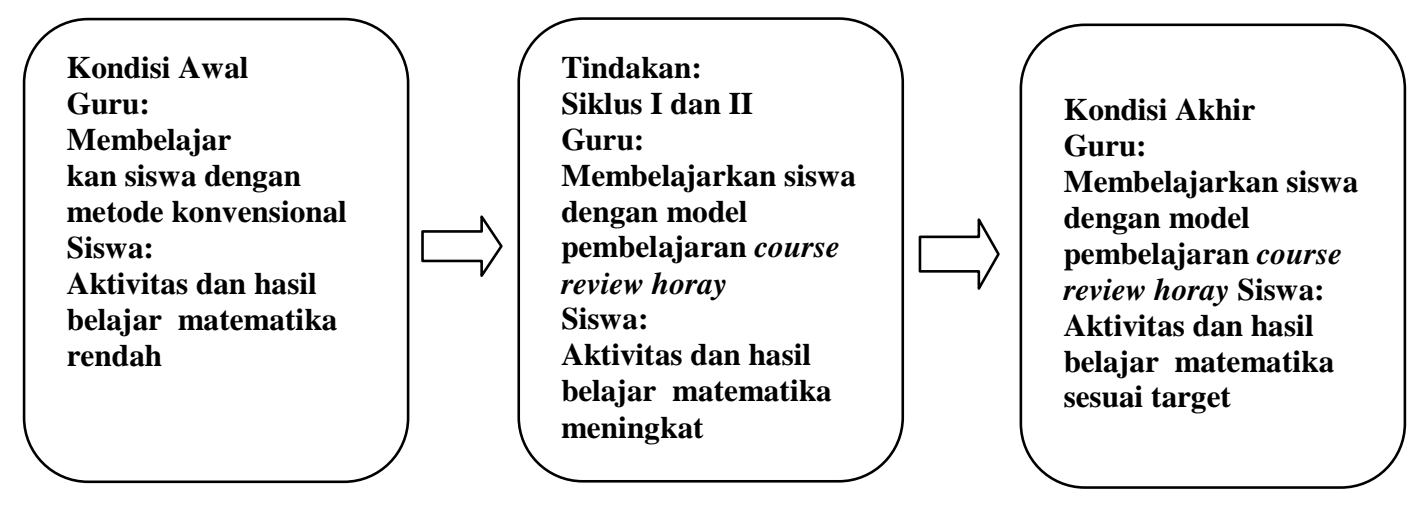

Gambar 1. Kerangka Berpikir Penelitian

Hipotesis tindakan dalam penelitian ini adalah adalah "model pembelajaran course review horay dapat meningkatkan aktivitas dan hasil belajar matematika tema pengalamanku bagi siswa kelas I SD 3 Tenggeles, Mejobo Kudus Semester II Tahun Pelajaran 2017/2018.

\section{METODE PENELITIAN}

Penelitian dilakukan pada bulan Januari sampai April 2018. Lokasi penelitian ini di kelas 1 SD 3 Tenggeles, Kecamatan Mejobo, Kabupaten Kudus. Peneliti menggunakan kelas tersebut dikarenakan hasil belajar dan aktivitas belajar siswa rendah. SD 3 Tenggeles Kecamatan Mejobo Kabupaten Kudus terletak di dekat persawahan sehingga nyaman untuk pembelajaran karena suasana pada saat pembelajaran jauh dari kebisingan. Fasilitas sekolah juga sangat memadai sehingga dapat dilakukan pembelajaran yang kondusif.

Subjek penelitian ini adalah siswa kelas 1 SD 3 Tenggeles Kecamatan Mejobo Kabupaten Kudus tahun pelajaran 2017/2018 dengan jumlah siswa 15 terdiri dari 7 siswa putra dan 8 siswa putri. Karakterstik siswa kelas 1 SD 3 Tenggeles Kecamatan Mejobo Kabupaten Kudus tahun pelajaran 2016/2017 sangat beragam, namun perhatian orang tua terhadap kemajuan pendidikan anaknya sangatlah terlihat dan sangat besar. Objek penelitian ini adalah adalah mata Pelajaran matematika tema pengalamanku yang merupakan materi pada semester 1 .

Bentuk data yang diambil yaitu data kuantitatif dan kualitatif: (1) Data aktivitas belajar siswa adalah data kualitatif terdiri dari jurnal refleksi kondisi awal, data aktivitas belajar matematika pada siklus 1, data aktivitas belajar matematika pada siklus 2, (2) Data hasil belajar matematika merupakan data kuantitatif terdiri dari data data kondisi awal tentang hasil belajar matematika ada di daftar nilai, hasil belajar matematika pada siklus 1, dan hasil belajar matematika pada siklus 2 .

Sumber data dari siswa kelas 1 SD 3 Tenggeles Kecamatan Mejobo Kabupaten Kudus tahun pelajaran 2017/2018 dengan jumlah siswa 15 terdiri dari 7 siswa putra dan 8 siswa putri sebagai sumber utama penelitian tindakan kelas.

Teknik pengumpulan data: (1) Teknik dokumentasi berupa jurnal refleksi pembelajaran digunakan untuk mencari data kondisi awal aktivitas belajar dan hasil belajar siswa. Dokumentasi aktivitas belajar dapat dilihat pada jurnal mengajar guru, sedangkan dokumentasi hasil belajar dapat dilihat pada daftar nilai, (2) Teknik pengamatan atau observasi digunakan untuk memperoleh data aktivitas belajar siswa pada siklus 1 dan 2. Pengamatan dan observasi dilakukan oleh teman sejawat selaku kolaborator yang bertugas mengamati siswa dengan memberikan check list pada lembar observasi, (3) Teknik tes tertulis digunakan untuk memperoleh data hasil belajar siswa pada siklus 1 dan 2 yang dilaksanakan pada tiap akhir siklus.

Alat pengumpulan data: (1) Dokumen daftar nilai untuk data hasil belajar Matematika siswa pada kondisi awal, butir soal tes tertulis untuk hasil belajar siswa pada siklus 1 serta rekapitulasi nilai formatif siklus 1 , butir soal tes tertulis untuk hasil belajar siswa pada siklus 2 serta rekapitulasi nilai formatif siklus 2, (2) Dokumen catatan personal siswa dan jurnal mengajar guru untuk data aktivitas belajar siswa kondisi awal, lembar observasi/pengamatan untuk mencari data aktivitas belajar siswa pada siklus 1 , lembar observasi/pengamatan untuk mencari data aktivitas belajar siswa pada siklus 2 . 
Teknik validitas data adalah untuk mengetahui keabsahan data yang diterima. Setiap informasi yang akan dipakai sebagai data peneltian harus diuji dan diperiksa dulu validitasnya, data tersebut dapat dipertanggungjawabkan. Teknik pengujian ini diproses dengan trianggulasi data.

Peneliti menggunakan 2 jenis trianggulasi, yaitu trianggulasi sumber dan trianggualasi waktu. Trianggulasi sumber merupakan teknik pengumpulan data yang sejenis dari berbagai sumber data yang berbeda, maksudnya adalah data tersebut dilakukan ricek kebenarannya dari sumber lain yang dianggap paham dengan data. Trianggulasi waktu artinya data tersebut di cek pada responden pertama pada waktu yang berbeda.

Teknik analisis data menggunakan: (1) Teknik kualitatif. Teknik yang digunakan untuk menganalisis aktivitas belajar siswa. Terdapat 3 data aktivitas belajar yaitu data aktivitas belajar pada kondisi awal, data aktivitas belajar pada siklus 1 dan data aktivitas belajar pada siklus 2 dianalisis menggunakan teknik deskriptif komparatif dilanjutkan dengan refleksi. Deskriptif komparatif yaitu dengan membandingkan data aktivitas belajar kondisi awal dengan data aktivitas belajar siklus 1, membandingkan data aktivitas belajar siklus 1 dengan data aktivitas belajar siklus 2 dan membandingkan data aktivitas belajar kondisi awal dengan data aktivitas belajar kondisi akhir.

Sementara refleksi adalah membuat simpulan berdasarkan deskriptif komparatif kemudian memberi ulasan atas simpulan tersebut untuk menentukan perlu tidaknya siklus berikutnya; (2) Teknik kuantitatif. Teknik yang digunakan untuk menganalisis data hasil belajar siswa. Terdapat 3 data hasil belajar siswa, yaitu data hasil belajar pada kondisi awal, siklus 1, dan siklus 2 dianalisis menggunakan teknik deskriptif komparatif dilanjutkan dengan refleksi. Deskriptif komparatif yaitu dengan membandingkan data hasil belajar kondisi awal dengan data hasil belajar siklus 1, membandingkan data hasil belajar siklus1dengan data hasil belajar siklus 2, dan membandingkan data hasil belajar kondisi awal dengan data hasil belajar kondisi akhir.

Indikator keberhasilan ditentukan berdasarkan proses. Keberhasilan yang diukur berdasarkan proses, yaitu apabila dalam penelitian ini terjadi peningkatan aktivitas dan hasil belajar siswa sebelum diadakannya tindakan. Hal ini dapat dilihat adanya perubahan aktivitas dan hasil belajar dalam kegiatan pembelajaran matematika tema peristiwa alam menggunakan model pembelajaran course review horay.
Indikator keberhasilan produk, di deskripsikan dari keberhasilan siswa dalam pembelajaran matematika dengan menggunakan model pembelajaran course review horay ini.

Kriteria keberhasilan produk dalam pembelajaran matematika dengan menggunakan model pembelajaran course review horay, untuk aktivitas belajar siswa menggunakan tolak ukur apabila rata-rata kelas aktivitas belajar siswa mencapai $\geq 75$.

Sedangkan hasil belajar siswa kriteria keberhasilan produk dalam pembelajaran matematika dengan menggunakan model pembelajaran ini, menggunakan tolak ukur Kriteria Ketuntasan Minimal (KKM) matematika yang ada di sekolah, yaitu pencapaian $\geq 75$.

Prosedur Penelitian Tindakan Kelas (PTK) ini sendiri terdiri dari beberapa siklus. Tiap siklus dilaksanakan sesuai perubahan yang di capai seperti yang telah didesain dalam faktorfaktor yang diselidiki. Siklus 1 dan 2 berlangsung pada 4 pertemuan. Variabel yang diteliti sebagai tindakan ada dua yaitu model pembelajaran course review horay sebagai variabel bebas serta aktivitas dan hasil belajar siswa sebagai variabel terikat.

Prosedur pelaksanaan Penelitian Tindakan Kelas (PTK) ini setiap siklus meliputi perencanaan, pelaksanaan tindakan, pengamatan dan refleksi. Langkah-langkah tersebut dapat digambarkan sebagai berikut.

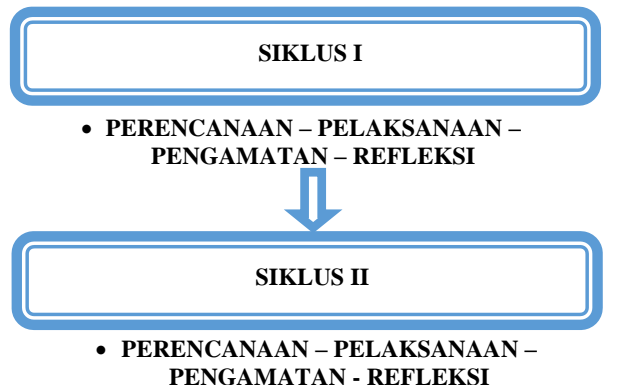

Gambar 2. Pelaksanaan Tindakan

\section{HASIL DAN PEMBAHASAN}

Hasil penelitian yang diuraikan adalah data mengenai aktivitas dan hasil belajar siswa dalam pembelajaran matematika sebelum menggunakan model pembelajaran course review horay. Pelaksanaan tindakan pada tiap-tiap siklus untuk meningkatkan aktivitas dan hasil belajar matematika siswa dengan menggunakan model pembelajaran course review horay.

Di bawah ini akan peneliti sajikan pula perbandingan aktivitas belajar kondisi awal dan kondisi akhir. 
Tabel 1. Perbandingan Aktivitas Belajar Kondisi Awal, Kondisi Akhir

\begin{tabular}{lll}
\hline Kriteria & Kondisi Awal & Kondisi Akhir \\
\hline Rata-rata & 69 & 78 \\
$\begin{array}{l}\text { Aktivitas } \\
\text { Siswa }\end{array}$ & \\
$\begin{array}{l}\text { Indikator } \\
\text { Keberhasilan }\end{array}$ & 75 & 75 \\
\hline
\end{tabular}

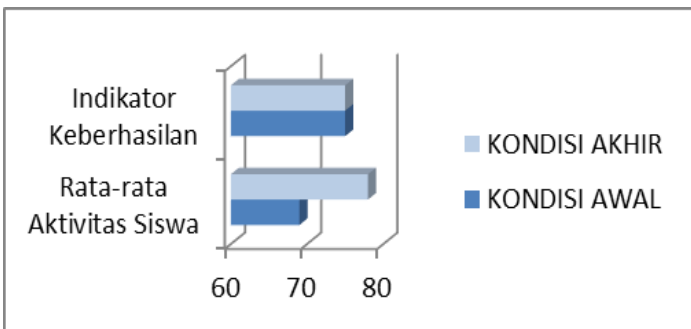

Gambar 2. Perbandingan Aktivitas Belajar Kondisi Awal, Kondisi Akhir

Dari data di atas dapat dijelaskan bahwa aktivitas siswa terjadi peningkatan sebesar 9 poin dari kondisi awal 69 ke kondisi akhir 78.

\section{Hasil Belajar Siswa}

Di bawah ini akan peneliti sajikan pula perbandingan hasil belajar kondisi awal dan kondisi akhir.

Tabel 2. Perbandingan Aktivitas Belajar Kondisi Awal, Kondisi Akhir

\begin{tabular}{lll}
\hline Kriteria & $\begin{array}{l}\text { Kondisi } \\
\text { Awal }\end{array}$ & $\begin{array}{l}\text { Kondisi } \\
\text { Akhir }\end{array}$ \\
\hline Rata-rata & 69 & 88 \\
Nilai & 80 & 100 \\
Tertinggi & & \\
Nilai & 60 & 80 \\
Terendah & & \\
KKM & $\mathbf{7 5}$ & $\mathbf{7 5}$ \\
\hline
\end{tabular}

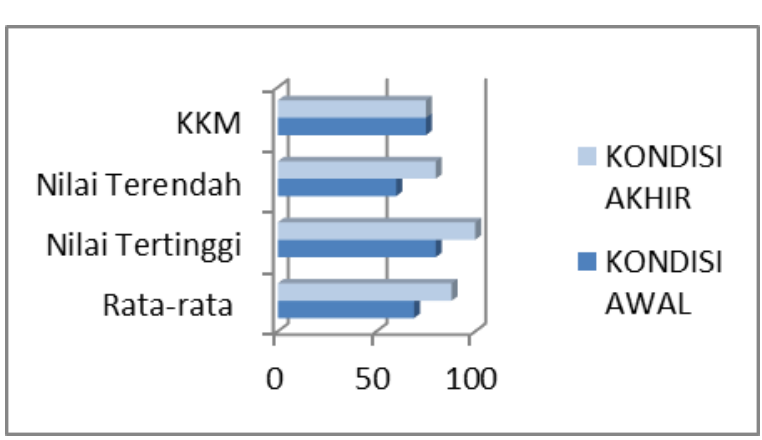

Gambar 3. Perbandingan Hasil Belajar Kondisi Awal, Kondisi Akhir

Dari data di atas dapat dijelaskan bahwa hasil belajar siswa terjadi peningkatan sebesar 20 poin dari kondisi awal 69 ke kondisi akhir 88 .
Pada kondisi awal kesalahan peneliti belum memanfaatkan salah satu model pembelajaran dengan siswa sebagai subjek pembelajaran bukan objek pembelajaran. Sehingga hanya menghasilkan aktivitas belajar 69 di bawah indikator kinerja 75.

Padahal matematika perlu diberikan kepada semua siswa mulai dari sekolah dasar untuk membekali siswa dengan kemampuan berpikir logis, analitis, sistematis, kritis, dan kreatif, serta kemampuan bekerjasama. Kompetensi tersebut diperlukan agar siswa dapat memiliki kemampuan memperoleh, mengelola, dan memanfaatkan informasi untuk bertahan hidup pada keadaan yang selalu berubah, tidak pasti, dan kompetitif. Peneliti memilih model pembelajaran course review horay siswa bisa belajar dengan menyenangkan tanpa ada rasa tertekan dengan konsep yang sedang dipelajari. Model pembelajaran course review horay dapat membuat siswa dengan mudah menyerap konsep-konsep yang dipelajari, sebab siswa terjun langsung dalam memecahkan masalah.

Langkah pembelajaran yang peneliti tempuh guru menyampaikan kompetensi yang ingin dicapai. Guru menyajikan materi pelajaran sesuai dengan topik. Guru membagi siswa dalam kelompok-kelompok. Siswa diminta membuat kartu atau kotak sesuai dengan kebutuhan. Kartu atau kotak tersebut kemudian diisi dengan nomor yang ditentukan guru. Guru membaca soal secara acak dan siswa menuliskan jawabannya di dalam kartu atau kotak yang nomornya disebutkan guru. Setelah pembacaan soal dan jawaban siswa ditulis di dalam kartu atau kotak, guru dan siswa mendiskusikan soal yang telah diberikan tadi. Bagi pertanyaan yang dijawab dengan benar, siswa memberi tanda check list $(\sqrt{ })$ dan langsung berteriak "horee!!" atau menyanyikan yel-yelnya.

Nilai siswa dihitung dari jawaban yang benar dan yang banyak berteriak "horee!!". Dan guru memberikan reward kepada kelompok yang memperoleh nilai tertinggi atau yang paling sering memperoleh "horee!!".

Kondisi awal aktivitas belajar mendapat poin 69 , siklus I meningkat menjadi 74 , dan siklus II mencapai 78. Dari kondisi awal ke kondisi akhir terjadi peningkatan sebesar 12 poin. Dengan membelajarkan siswa menggunakan model pembelajaran course review horay, maka aktivitas belajar siswa dapat ditingkatkan. Hal tersebut sesuai pendapat Huda (2013:231) bahwa kelebihan model pembelajaran ini adalah: semangat belajar yang meningkat karena suasana pembelajaran berlangsung menyenangkan dan skill kerja sama antar siswa semakin terlatih. 
Model pembelajaran course review horay pada uraian di atas telah berhasil meningkatkan aktivitas belajar siswa. peningkatan aktivitas siswa tersebut memberikan dampak juga terhadap peningkatan hasil belajar siswa.

Hasil belajar siswa ini diukur dengan kegiatan tes yang dilakukan pada akhir siklus I dan II. Pada siklus I peneliti membuat 5 soal untuk mengukur hasil belajar siswa begitu pula pada siklus II peneliti juga membuat 5 soal untuk mengukur hasil belajar siswa.

Pencapaian hasil belajar yang meningkat dibuktikan dengan perolehan nilai rata-rata siswa pada kondisi awal mencapai 69 dengan nilai tertinggi 80 dan nilai terendah 60 sedangkan KKM matematika 75 .

Pada siklus I nilai rata-rata mencapai 72 dengan nilai tertinggi 100 dan nilai terendah 60 sedangkan KKM matematika 75. Kemudian pada siklus II perolehan nilai rata-rata siswa meningkat menjadi 88 dengan nilai tertinggi 100 dan nilai terendah 80 sedangkan KKM matematika 75.

Kondisi awal hasil belajar 69, siklus I meningkat menjadi 72 dan siklus II mencapai 88 Dari kondisi awal ke kondisi akhir terjadi peningkatan sebesar 20 poin. Peningkatan yang cukup signifikan.

Peningkatan hasil belajar siswa ini terjadi karena penerapan model pembelajaran course review horay, dalam pembelajaran kooperatif, siswa belajar bersama dalam kelompokkelompok kecil yang saling membantu satu sama lain. Kelas disusun dalam kelompok yang terdiri atas empat siswa dengan kemampuan heterogen. Maksud kelompok heterogen adalah terdiri atas campuran kemampuan siswa, jenis kelamin, dan suku. Hal ini bermanfaat untuk melatih siswa menerima perbedaan cara bekerja dengan teman yang berbeda latar belakangnya.

Model pembelajaran course review horay merupakan kegiatan belajar mengajar antara guru dan murid, namun tidak dilakukan di dalam kelas, tetapi dilakukan di luar kelas atau alam terbuka, sebagai kegiatan pembelajaran siswa.

Dari uraian di atas maka dapat disimpulkan bahwa perolehan aktivitas dan hasil belajar yang maksimal maka model pembelajaran course review horay dapat meningkatkan aktivitas dan hasil belajar matematika tema pengalamanku bagi siswa kelas I SD 3 Tenggeles Kecamatan Mejobo Kabupaten Kudus Semester II Tahun Pelajaran 2017/2018.

Hal ini sesuai dengan pendapat Huda (2013:231) model pembelajaran course review horay memiliki kelebihan: (1) strukturnya yang menarik dan dapat mendorong siswa untuk dapat terjun ke dalamnya, (2) model yang tidak monoton karena diselingi dengan hiburan, sehingga suasana tidak menegangkan, (3) semangat belajar yang meningkat karena suasana pembelajaran berlangsung menyenangkan, (4) skill kerja sama antar siswa semakin terlatih.

\section{SIMPULAN}

Berdasarkan hasil penelitian dan pembahasan, disimpulkan bahwa penggunaan model pembelajaran course review horay dapat meningkatkan aktivitas dan hasil belajar matematika tema pengalamanku bagi siswa kelas I SD 3 Tenggeles Kecamatan Mejobo Kabupaten Kudus Semester II Tahun Pelajaran 2017/2018. Sebagai indikasinya: (1) Aktivitas belajar matematika tema pengalamanku terus meningkat pada tiap siklus. Kondisi awal aktivitas belajar 69, siklus I meningkat menjadi 74 dan siklus II mencapai 78. Dari kondisi awal ke kondisi akhir terjadi peningkatan sebesar 9, (2) Hasil belajar matematika tema pengalamanku terus meningkat pada tiap siklus. Kondisi awal hasil belajar 69 , siklus I meningkat menjadi 72 dan siklus II mencapai 88. Dari kondisi awal ke kondisi akhir terjadi peningkatan sebesar 20.

Berdasarkan pada kesimpulan diatas, saran bagi guru adalah sebagai berikut: (1) Penggunaan model pembelajaran course review horay dalam pembelajaran matematika di SD hendaknya dapat digunakan sebagai alternatif dalam rangka meningkatkan aktivitas dan hasil belajar siswa, (2) Diharapkan agar guru selalu aktif, kreatif, dan inovatif untuk mengemas pembelajaran dengan metode yang tepat dalam pembelajaran matematika seperti model pembelajaran course review horay sehingga dapat dikembangkan lebih lanjut dalam rangka meningkatkan aktivitas dan hasil belajar siswa.

\section{DAFTAR PUSTAKA}

Hamalik, Oemar. 2011. Psikologi Belajar Mengajar. Bandung: Sinar Baru Algensindo.

Huda, Miftahul. 2013. Cooperative Learning. Yogyakarta: Pustaka Pelajar.

Karso, dkk. 2014. Pendidikan Matematika 1. Universitas Terbuka. Tangerang.

Kunandar. 2013. Langkah Mudah Penelitian Tindakan Kelas Sebagai Pengembangan Profesi guru. Jakarta: Pt Rajawali Pers.

Rusman. 2011. Model-Model Pembelajaran. Jakarta: Raja Grafindo Persada.

Rusita, Evi. 2017. Penerapan Metode Course Review Horay (CRH) Pada Pembelajaran Matematika Siswa Kelas 
Suprihartini

Anargya: Jurnal Pendidikan Matematika, Vol. 2 No.2, Oktober 2019

IV di SD Negeri $03 \quad$ Nangsri

Kebakkramat Karanganyar Tahun

Ajaran 2017/2018.

http://repository.radenintan.ac.id/2651/1

/Skripsi_Full.pdf

Sardiman, A. M. 2012. Interaksi dan Motivasi Belajar Mengajar. Jakarta: Radjagrafindo Perkasa.

Saputri, Mawar Kuning Nugraheni. 2016. Penerapan model cooperative learning tipe course review horay untuk meningkatkan aktivitas dan hasil belajar matematika siswa kelas IV SD Negeri 1 Metro Timur. http://digilib.unila.ac.id/22711/3/SKRIP SI\%20TANPA\%20BAB\%20PEMBAH ASAN.pdf

Suprijono, Agus. 2012. Cooperative Learning: Teori dan Aplikasi PAIKEM. Jogjakarta: Pustaka Pelajar.
Suwangsih, Erna; Tiurlina. 2010. Model Pembelajaran Matematika. Bandung: UPI Press.

Thobroni. 2015. Belajar dan Pembelajaran: Teori dan Praktik. Yogyakarta: ArRuzz Media 